\title{
Decision-making for the demolition or adaptation of buildings
}

1 Hannah Baker MA (Cantab), MA, MRes PhD student, University of Cambridge, Cambridge, UK (corresponding author: heb51@cam.ac.uk) (Orcid:0000-0002-8103-5656)

2 Alice Moncaster MA (Cantab), MSc, PhD, CEng, MICE Lecturer and Director of the IDBE Masters Course, University of Cambridge, Cambridge, UK
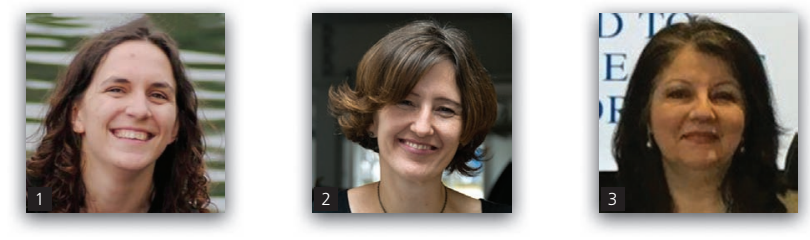

3 Abir Al-Tabbaa PhD, CEng, FICE

Professor of Civil and Environmental Engineering, University of Cambridge, Cambridge, UK

This paper considers why the decision may be made either to demolish or adapt existing buildings on brownfield sites and compares real-life decisions to those produced by theoretical design-support tools. Five case studies, including three individual buildings and two master plan sites of multiple buildings, were investigated through interviews with stakeholders. Reasons for retention included heritage value, architectural quality and government incentives, while reasons for demolition included maximising land value, lack of architectural significance and poor building condition. The analysis showed that the theoretical tools were useful for their intended purpose of analysing a portfolio of assets but that they could be improved by providing higher weightings for heritage values and extending the tools to assess different end uses and forms of adaptation. By testing the tools on master plan sites, the paper also identifies urban design variables, such as land efficiency, which would need to be incorporated for this purpose.

\section{Introduction}

The UK's Housing and Planning Act 2016 aims to 'unlock brownfield land to provide homes faster' (DCLG and Lewis, 2016). The demand to redevelop brownfield sites not only in the UK but also worldwide is indicated by research from around the globe, including Singapore (Lin and Low, 2012), Australia (Langston and Smith, 2012) and the Netherlands (Geraedts and Van der Voordt, 2007). During the redevelopment of these brownfield sites, it is vital that the decision to demolish or retain buildings takes into account different sustainability issues, such as the impact on the environment, surrounding economy and community (Love and Bullen, 2009).

Decisions are made for a variety of different reasons. Some developers will prefer demolishing existing buildings and replacing them with new build as it allows for the 'sweeping away of the old (structures, services, designs and layouts)' (Plimmer et al., 2008: p. 13) and provides a blank canvas to work from (Wilkinson, 2011). It is also not always economically viable or desirable to keep buildings because of technical difficulties, including poor building condition and difficulties meeting building regulations (Plimmer et al., 2008). However, others argue that demolition does not consider the benefits of building retention, such as savings in embodied energy and the importance of the building within a local, national or global context (Power, 2008). The complex and multidimensional nature of this issue has led to the development of a number of design-support tools which aim to incorporate the relevant factors and support the decision-making process.

This research identifies firstly why the decisions were made to demolish or adapt buildings on real projects in the UK and then compares these with existing academic decision tools. The role and viewpoints of engineers are linked with those of other stakeholders by discussing technical aspects alongside less tangible values. The main objectives of this paper are therefore to investigate why people chose to demolish or adapt existing buildings and what decision tools currently exist and how they can be improved.

\section{Literature review: studies exploring the decision to demolish or adapt existing buildings}

\subsection{Brownfield redevelopment, adaptation and demolition}

Brownfield sites are those which have been previously developed, and some form of intervention is required to bring them back into use. The Conservative Party's 2015 manifesto stated that they would ensure 'brownfield land is used as much as possible for new development' (Smith, 2016: p. 5). The decision on what 
should happen to the existing buildings on these sites is complex and involves a range of stakeholders and decision-makers, with various authors identifying these as engineers, architects, environmental managers, planners, developers, quantity surveyors and urban designers, who will often have different priorities (Bullen and Love, 2010; Dixon et al., 2008; Pinder et al., 2013). Options for the asset owners include doing nothing and waiting for the market to change, selling the building, adapting the building or demolishing and building something new (Remøy and Van der Voordt, 2006). The concept of adaptation is not black and white; there are different forms depending on the level of intervention. Douglas (2006) described these as preservation, conservation, refurbishment, rehabilitation, renovation, remodelling, respiration and demolition. The decision will also depend on the characteristics of the site itself, with different categories defined by Dixon et al. (2008) (Figure 1).

\subsection{Benefits and drawbacks of adaptation compared to demolition}

Table 1 displays the most frequently cited benefits and drawbacks associated with adaptation and demolition as identified in the

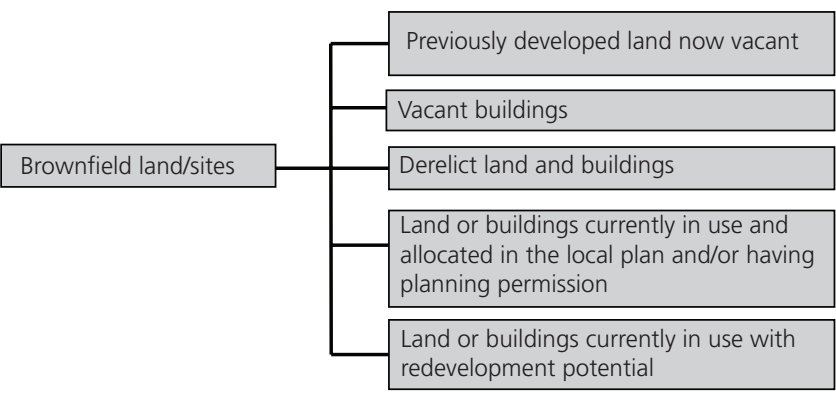

Figure 1. Different types of brownfield sites. Data source: Dixon et al. (2008) academic literature. Advantages of adaptation include savings in embodied energy and conservation of heritage values, while demolition may be favoured if the building is in poor condition or there are difficulties meeting building regulations, as this can increase the financial risk and overall cost of the project.

Gaspar and Santos (2015: p. 386) described the embodied energy of materials as 'a concept that allows the measurement of environmental impact, considering energy expenditure associated to the extraction, transportation, processing, on-site assembly and performance of materials, during their expected life cycle'. If a building is retained rather than demolished, usually, fewer materials are required for the project, thus lowering embodied energy and associated carbon dioxide emissions. However, a counterargument is that existing buildings cannot reach the same operational energy standards as new builds, which could cause the emissions over the entire life cycle of the building to be higher (Ball, 2002; Davis Langdon, 2008; Thomsen and van der Flier, 2009). Palmer et al. (2003) showed that existing buildings could be made as energy efficient as new builds, but other variables will affect this decision, such as cost and whether the building will be owner occupied.

The Oxford Dictionary (Oxford Dictionaries, 2016) provides a broad definition of heritage as 'valued objects and qualities, such as historic buildings and cultural traditions that have been passed down from previous generations'. If a heritage building is deemed significant, the National Planning Policy Framework requires applicants to provide a 'clear and convincing justification' for its harm or loss (DCLG, 2012: p. 31). This is often supported by designations of buildings by government bodies, such as Historic England, which provide protection in the planning process. Ball (2002) indicated that there is a growing appreciation and wider acceptance of heritage value in the built environment, and several academics have researched its economic value, with many

Table 1. Advantages and disadvantages of adaptation over demolition

\begin{tabular}{|c|c|}
\hline Advantages & References \\
\hline Less material use (embodied energy) & $\begin{array}{l}\text { Ball (2002), Bullen and Love (2010), Clegg (2012), Conejos et al. (2011), Gaspar } \\
\text { and Santos (2015), Itard and Klunder (2007), Lin and Low (2012), Remøy and } \\
\text { Van der Voordt (2006), Thomsen and Flier (2009), Wilkinson et al. (2014), } \\
\text { Yung and Chan (2012) }\end{array}$ \\
\hline Heritage value/conservation & $\begin{array}{l}\text { Ball (2002), Bullen and Love (2010), Remøy and Van der Voordt (2006), Wang } \\
\text { and Zeng (2010), Watson (2009), Wilkinson et al. (2014), Yung and Chan } \\
\text { (2012) }\end{array}$ \\
\hline $\begin{array}{l}\text { Typically faster than demolition and new build, including } \\
\text { time to obtain planning permission }\end{array}$ & $\begin{array}{l}\text { Power (2008), Remøy and Van der Voordt (2006), Watson (2009), Wilkinson et } \\
\text { al. (2014) }\end{array}$ \\
\hline Disadvantages & References \\
\hline Poor building quality/condition leading to increased costs & $\begin{array}{l}\text { Ball (2002), Bullen and Love (2010), Lin and Low (2012), Thomsen and Flier } \\
\text { (2009), Van der Flier and Thomsen (2006), Wilkinson et al. (2014) }\end{array}$ \\
\hline $\begin{array}{l}\text { Previous building does not conform to building regulations - } \\
\text { for example, thermal performance, acoustics, fire }\end{array}$ & $\begin{array}{l}\text { Bullen and Love (2010), Lin and Low (2012), Plevoets and Van Cleempoel } \\
\text { (2011), Remøy and Van der Voordt (2006), Watson (2009), Wilkinson et al. } \\
\text { (2014), Yung and Chan (2012) }\end{array}$ \\
\hline $\begin{array}{l}\text { Accurate drawings may not be available/lack of recorded } \\
\text { information }\end{array}$ & $\begin{array}{l}\text { Bullen and Love (2010), Remøy and Van der Voordt (2006), Wilkinson et al. } \\
\text { (2014) }\end{array}$ \\
\hline
\end{tabular}


Table 2. The Transformation Meter - examples of criteria

\begin{tabular}{llll} 
Main criterion & \multicolumn{1}{c}{ Aspect } & \multicolumn{1}{c}{ Gradual criterion } & Yes/no \\
\hline $\begin{array}{l}\text { Building } \\
\text { Functional }\end{array}$ & Extendibility & Not horizontally or vertically extendable & Yes/no \\
$\begin{array}{l}\text { Technical } \\
\text { Location }\end{array}$ & Structure dimension & Building depth: $<10 \mathrm{~m}$ & Yes/no \\
Functional & Public transport & Distance to railway station: $>1 \mathrm{~km}$ & Yes $/ \mathrm{no}$ \\
Legal & Ownership of land & Lease & Yes/no
\end{tabular}

Adapted from Wilkinson et al. (2014: pp. 121-134)

showing that the historic environment creates a price premium (Ahlfeldt et al., 2012; Been et al., 2016; Lazrak et al., 2013; Noonan and Krupka, 2011; Ruijgrok, 2006). Despite this range of studies, others describe the difficulty of quantifying heritage without the support of 'hard evidence' (Wilkinson et al., 2014).

The cost of an adaptation project will be dependent on the building condition, which affects the complexity of the intervention and the associated risks (Bullen and Love, 2011; Plimmer et al., 2008). In the Institution of Structural Engineers' guide on structural surveys, common issues identified include structural instability, poor detailing, age- and quality-related deteriorations, poor workmanship, damp and water penetration, thermal movement and outdated services (IStructE, 2008). Sometimes there are problems accessing buildings to conduct inspections. There is also the risk that during the construction work, unexpected problems can arise which were not identified during initial inspections (Picco et al., 2012; Wilkinson et al., 2014).

If building work is being undertaken during an adaptation project, as defined in regulation 3 of the Building Regulations 2010 (HMG, 2010), regulations will need to be conformed to. In some cases, this can cause complications, particularly if the historical character of the building cannot be compromised. For this reason, there are some exemptions, such as energy efficiency requirements for listed buildings (Historic England, 2016) emphasising the need to combine technical and intangible considerations.

\subsection{Decision-making criteria and tools}

Criteria used to assess the adaptation potential of existing buildings have been researched by a range of academics (Bullen and Love, 2010; Dutta and Husain, 2009; Kutut et al., 2014; Lin and Low, 2012; Wilkinson et al., 2014). For example, Kutut et al. (2014) used an analytical hierarchy process and pairwise comparison to weight criteria, including whether or not the building requires investment, its heritage value and the state of the building. Other academics have expanded on the provision of the criteria and created tools which aid decison-makers. Geraedts and Van der Voordt's (2007) Transformation Meter and Langston and Smith's (2012) IconCUR have been designed for asset managers to assess the buildings within their portfolio and help indicate the most appropriate form of intervention (Wilkinson et al., 2014).
The Transformation Meter was designed in the Netherlands for asset managers to assess rapidly the adaptation potential of vacant office buildings in their portfolio to residential dwellings (Geraedts and Van der Voordt, 2007). The tool is divided into five stages which require yes/no answers. Stage 1, the quick scan, identifies eight criteria. If any of these are met, then that building should not be considered for adaptation. These criteria include the following: the free ceiling height is less than $2.6 \mathrm{~m}$ and the zoning plan does not permit modification. If the quick scan is passed, then stage 2 assesses the overall feasibility of adaption using a combination of building and location criteria - some examples are provided in Table 2. A transformation class is then assigned (stage 3 ) by calculating how many criteria have been met using different values for the yes/no answers (see Table 3). If the building is found to be transformable or has excellent transformability, Geraedts and Van der Voordt (2007) recommend that a financial feasibility study (stage 4) and an identification of risks (stage 5) are undertaken.

Academics in Australia have created a three-dimensional (3D) spatial tool, called IconCUR (Langston and Smith, 2012). IconCUR uses multiple criteria to assess the performance of an asset during its life cycle in the early stages of decision-making and has been 'integrated into commercial asset management software' (Langston and Smith, 2012: p. 412). The Transformation Meter looks only at adaptation potential, whereas IconCUR identifies what action should be taken: renovate/preserve, retain/extend, reuse/adapt or reconstruct/dispose. Scores $(1=$ very low; $5=$ very high $)$ are assigned to the three axes: condition, utilisation and reward by using a range of weighted criteria. To assess the condition ( $x$ axis) of the building, the design standard, maintained service level and regulatory compliance are

Table 3. Assigning transformation classes by using the Transformation Meter

\begin{tabular}{ll} 
Transformation score $^{\text {a }}$ & \multicolumn{1}{c}{ Transformation class } \\
$0-40$ & 1: Excellent transformability \\
$41-80$ & 2: Transformable \\
$81-120$ & 3: Limited transformability \\
$121-160$ & 4: Very poor transformability \\
$161-199$ & 5: Not transformable
\end{tabular}

a The transformation score equals the sum of the number of yes answers for location criteria multiplied by five and the number of yes answers for building characteristics multiplied by three

Adapted from Geraedts and Van der Voordt (2007: p. 22) 
scored for the building's structure, exterior envelope, interior finishes, engineering services and external works. For utilisation ( $y$ axis), the demand and relevance; fitness for purpose and user satisfaction of the internal space, external space and outdoor site area; equipment and fit out; and engineering systems are assessed. The $z$ axis, reward, has two scores - one score for the collective utility which takes into account the economic performance and cultural, heritage and environmental values; the second score considers different stakeholders' interest/involvement in the short-, mediumand long-terms. The reward is calculated by multiplying the collective utility and stakeholder interest scores together and then dividing by five. The action to be taken is determined by the $x$ and $y$ axes, and the value of this intervention is determined by the reward, $z$ axis. The overall score is used to plot the decision within a 3D framework, as depicted in Figure 2.

\section{Methodology}

Five sites within Birmingham, UK, were selected as case studies for consideration, combining the need for an in-depth analysis and the ability to assess a broad spectrum of strategies (Table 4). These cases were chosen based on prior knowledge of the area and recommendations made during interviews with Birmingham City Council. All sites were chosen to be within Birmingham in order to allow comparison across sites within a single authority; Birmingham is currently experiencing high levels of redevelopment (Birmingham City Council, 2015). Overall, 21 interviews (Table 5) were conducted and analysed alongside an analysis of planning documentation and media articles. The interviews were semistructured, allowing a set of predefined questions to be asked while considering the need for elaboration during the conversation (May, 2003). The methodology is supported by Daly et al. (2013), who discuss the use and value of qualitative research methods in engineering design and how they can help facilitate the understanding of complex interactions and design systems.

Data collected from the case studies were used to evaluate the two decision-making tools discussed in the literature review: the

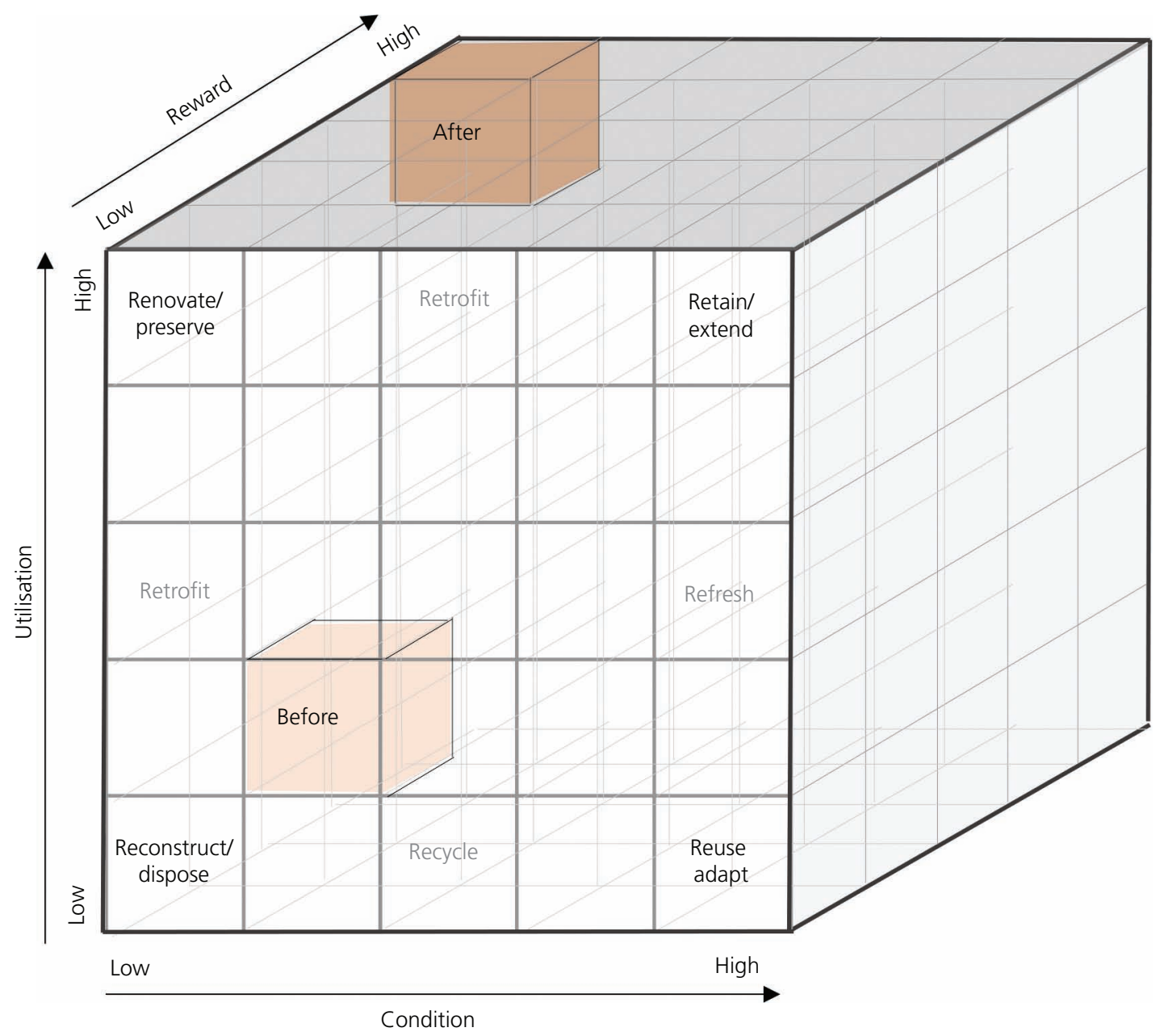

Figure 2. Three-dimensional IconCUR - showing the location of an asset before and after intervention. Reproduced and adapted from Wilkinson et al. (2014: pp. 230-249) 
Table 4. Case studies: their current status in terms of planning and construction and a brief description of site

\begin{tabular}{lll} 
Case study & \multicolumn{1}{c}{ Current status } & \multicolumn{1}{c}{ Brief description of site } \\
\hline $\begin{array}{l}\text { Fort Dunlop } \\
\text { One Snow Hill Plaza }\end{array}$ & $\begin{array}{c}\text { Completed in } 2007 \\
\text { Completed in } 2013\end{array}$ & $\begin{array}{l}\text { Former warehouse converted to offices, commercial use and hotel } \\
\text { Vacant office block converted to hotel }\end{array}$ \\
Selly Oak Hospital & $\begin{array}{c}\text { Completed in 2016 } \\
\text { Outline planning permission obtained in 2012; } \\
\text { construction of phase 1 begun in 2015 }\end{array}$ & $\begin{array}{l}\text { Vacant office block converted to residential units } \\
\text { Former hospital site being converted to residential development }\end{array}$ \\
Icknield Port Loop & Outline planning permission obtained in 2011 & Former industrial area being converted to residential development
\end{tabular}

Table 5. Stakeholders and number of interviews

\begin{tabular}{lc} 
Stakeholder & Number of interviews \\
\hline Architects & 3 \\
Building regulations enforcement officers & 1 \\
Commercial agents & 1 \\
Developers/freehold owners & 4 \\
Ecologists & 1 \\
Engineers & 2 \\
Local authority staff & 5 \\
Planning consultants & 3 \\
Urban designers & 1
\end{tabular}

Note: some interviewees were attached to more than one case-study investigation

Transformation Meter and IconCUR. These tools were chosen due to their relevance to the decision being evaluated. The testing is also of use to the original authors, as it will help highlight potential improvements with the tools. For example, Geraedts and Van der Voordt (2007: p. 21) stated that 'more case studies are needed both to test the reliability and validity of the transformation meter'.

The testing assumes that the buildings were in the same state they were when the decision was made to adapt or demolish and compares the decision generated by the theoretical tools to the decision made in real life, with scores assigned based on an interpretation of the available data.

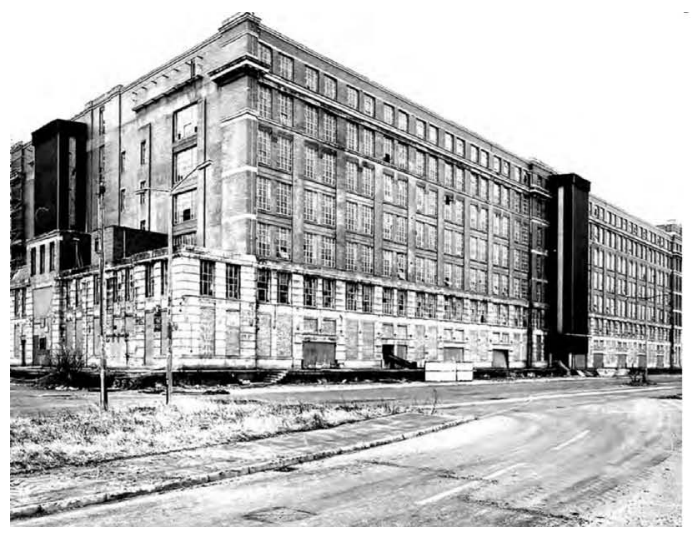

\section{Case studies}

\subsection{Case study 1: Fort Dunlop}

Fort Dunlop was a former tyre factory/warehouse that became derelict in the 1980s. At the turn of the century, Advantage West Midlands (a regional development agency, which was later taken over by English Partnerships) formed a joint venture with Urban Splash, a private development company (EGi, 2015). Their aim was to regenerate the building and turn it into a positive landmark which could be seen by people as they entered Birmingham by way of the M6 (Advantage West Midlands, 2012; McAllister, 2006). The conversion of the building into offices, retail space and a new hotel building began in 2004. One of the biggest challenges during the decision-making process was finding an appropriate use. Initially, the proposal included residential dwellings, but this was deemed inappropriate because of high noise levels generated from aeroplanes passing overhead and traffic on the nearby motorway.

The original building was constructed from wrought-iron columns cast in concrete on a $5.2 \mathrm{~m}$ structural grid with concrete floor slabs, and the entire building had a masonry facade. The architects and engineers worked with the existing grid of columns and maintained one of the structural cores. An original core was removed and replaced by a glazed wall requiring cross-bracing for lateral stability (Figure 3). Bringing natural lighting into the deep $52 \mathrm{~m}$ plan caused complications but was overcome by introducing a central light well. The original timber roof was demolished and

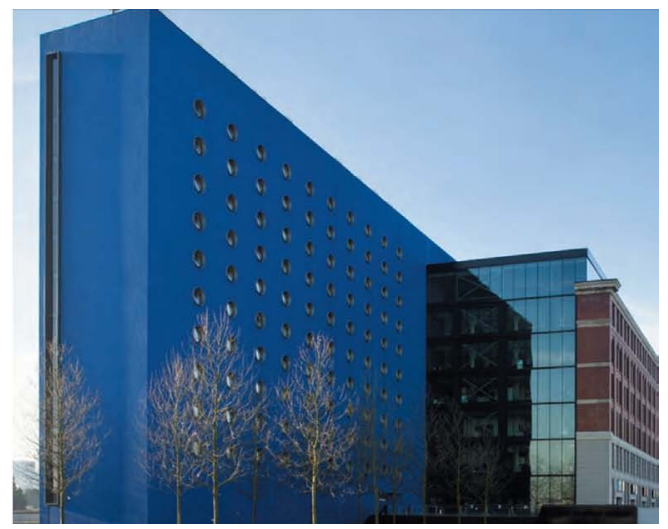

Figure 3. Fort Dunlop. Left: warehouse in derelict state before intervention. Right: newly built hotel attached to renovated warehouse. Source: ShedKM (2008) 
replaced with a new storey, constructed from a light steel frame with a green roof. New glazing is set back from the original elevation, freeing up space in the gap for services and avoiding complications with the interface between new windows and old brickwork (ShedKM, 2008). Despite initial surveys identifying these potential problems, alongside issues related to the condition of the building, such as spalling concrete and not meeting current fire regulations because of limited concrete cover, the warehouse was retained because of its importance to the nearby community, which is reflected in its status as a grade A locally listed building (Urban Splash, 2007).

\subsection{Case study 2: One Snow Hill Plaza}

One Snow Hill Plaza is a 21-storey concrete-framed tower, originally built as an office block in 1973. The conversion of the building into a 224-bedroom hotel (Figure 4) began in 2012. The load-bearing structure has been maintained and dictated the hotel's internal layout (Falconer Chester Hall, 2010). However, work on the ground and first floors was slightly more complex as two new voids were introduced to provide double-height spaces in the reception and dining room areas. An additional plant room was installed on the fourth floor due to the extra utility requirements for hotels compared to offices.

The principal driver for adaptation was the business premises renovation allowance (BPRA), which provides building owners and investors with a $100 \%$ tax allowance on costs incurred during the adaptation process (HMRC, 2014). There had been a previous scheme (by the Kenmore Group) to demolish the existing building and replace it with a new 29-storey office building targeting blue-chip companies which would 'provide Birmingham with a landmark gateway' (Anon, 2008). However, in 2009, the Kenmore Group went into administration and the building was sold.

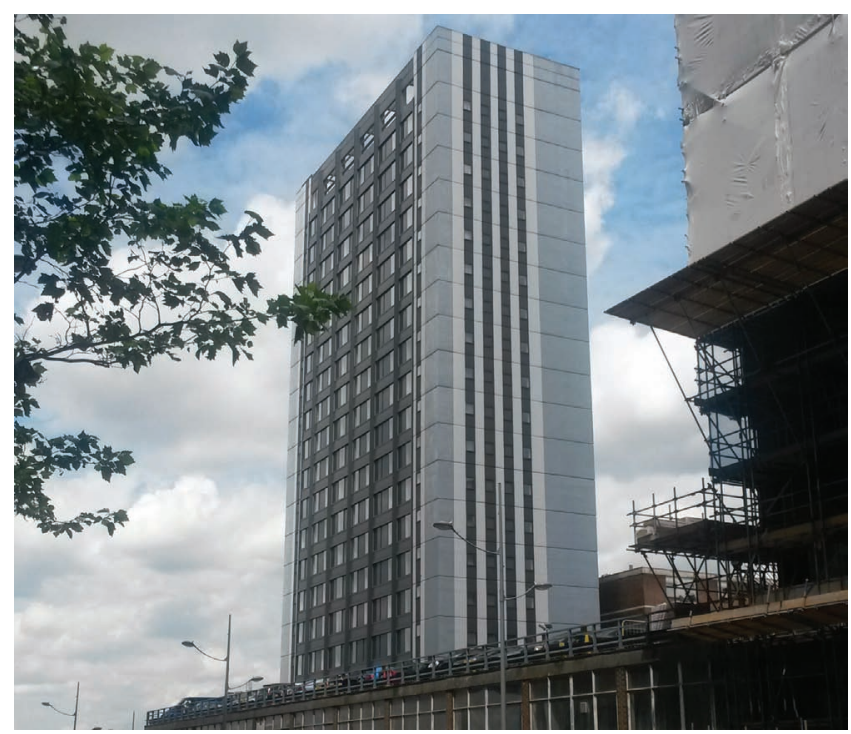

Figure 4. One Snow Hill Plaza post-adaptation

\subsection{Case study 3: One Hagley Road}

One Hagley Road is a 20-storey concrete-framed tower built in 1974. The tower was previously used as offices, but the unusually shaped floor plates were no longer appropriate for a contemporary open-plan office (Associated Architects, 2012). Consequently, the existing tower block was converted to over 260 residential dwellings (Figure 5). The driver for adaptation was the General Permitted Development Amendment Order 2013 (HMG, 2013) which allowed office buildings to be converted to residential dwellings without full planning permission provided the external facade of the building was not affected and other factors such as flooding were not exacerbated. The advantages of this for the developers were the reduced timescale to obtain approval and the lack of conditions attached.

Surveys showed that the existing building was in very good condition. The load-bearing structure consisting of concrete columns and structural core were maintained, and the residential units were designed within these constraints. As permitted development does not allow facade alterations, secondary glazing was added behind the existing facade to ensure that $U$ values (indicating the rate of heat transfer) were met. An additional planning application in 2014 was made to provide an extra 12 units and to convert the existing plant rooms to penthouse suites (Building Design Group Ltd, 2014). The properties were all sold within 5 months (off-plan) after going on the market (Brown, 2014).

\subsection{Case study 4: Selly Oak Hospital - master plan redevelopment site with multiple buildings}

The first development of Selly Oak Hospital began in the 1870s, and the site continued to run as a hospital until 2010 when functions moved to the New Queen Elizabeth Hospital (UHB and GVA Grimley Ltd., 2012). Outline planning permission was obtained by the University Hospitals Birmingham National Health Service Foundation Trust in 2013 to redevelop the area into a residential neighbourhood, and the site was then sold to Persimmon Homes, to redevelop the area into a residential neighbourhood (Pinsent Masons, 2015). In 2006, many of the

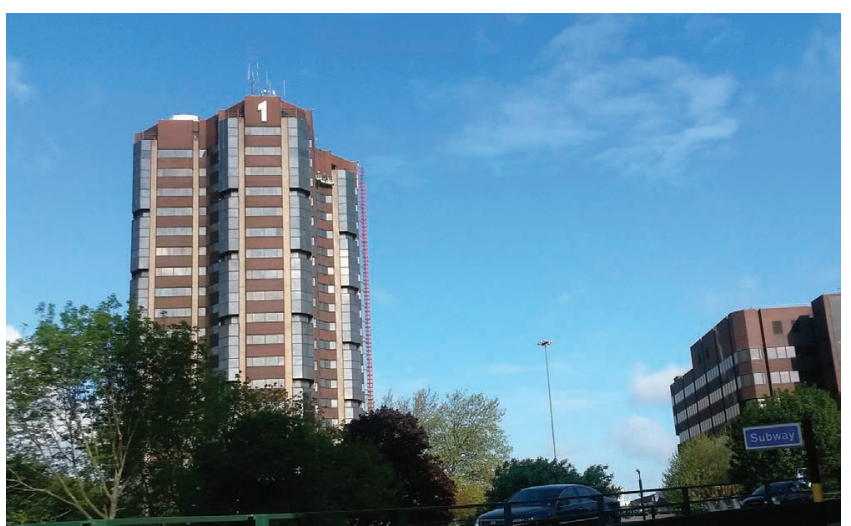

Figure 5. One Hagley Road during internal construction work 
buildings were spot-listed by English Heritage (now Historic England) for statutory listing. However, due to previous adaptations and extensions, English Heritage felt that the buildings' architectural interest had been compromised, and a national-listed status was not granted (UHB and GVA Grimley Ltd., 2012). In 2007, the local planning authority began preparing the site's supplementary planning guidance and recognised the positive impact that some of the buildings had on-site and, in 2009, the Birmingham City Council's principal conservation officer recommended that the same buildings become locally listed, and this was accepted (UHB and GVA Grimley Ltd., 2012).

During the design of the master plan, all the locally listed buildings were assessed by University Hospitals Birmingham by using the following criteria: heritage/architectural merit, urban design, policy, market conditions, regulations, community views and wider professional views (UHB and GVA Grimley Ltd., 2012). Eight of the 14 locally listed buildings analysed will be maintained due to their significance to the community, architectural merit, prominence on-site and need to leave a legacy (see Figure 6). Reasons for demolition included the location onsite compromising the maximisation of new development, the

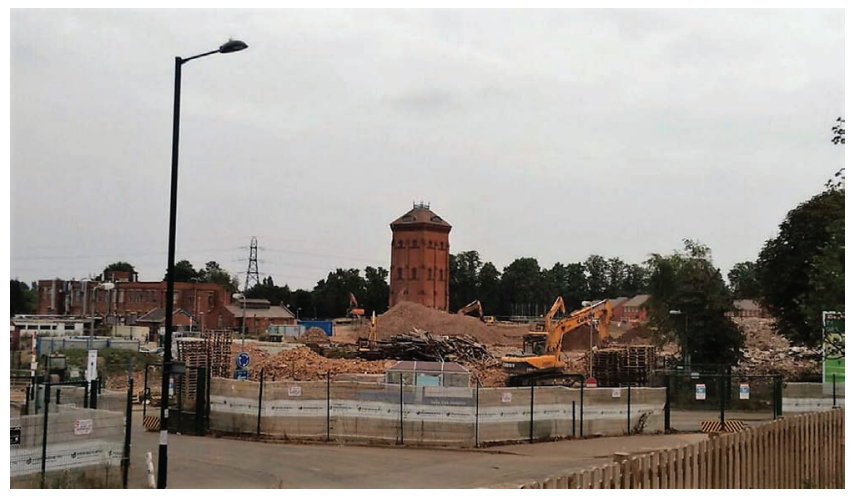

Figure 6. Selly Oak Hospital construction site. Water tower is being maintained as it is a landmark feature in the area building's dimensions being inappropriate for conversion and limited architectural quality due to previous alterations. The newer buildings (1960s) were all demolished.

\subsection{Case study 5: Icknield Port Loop - master plan redevelopment site with multiple buildings}

Icknield Port Loop is a former industrial site dating back to the nineteenth century. Outline planning permission was obtained in 2013 for the site to be converted to a residential development with up to 1150 dwellings and over $9000 \mathrm{~m}^{2}$ of office and retail spaces, alongside a hotel and community facilities (Birmingham City Council, 2011).

Within the outline planning application, two buildings were identified for retention, the former Stable Block (Figure 7) and Tube Works. These will be converted from industrial uses to commercial or retail. The urban designer stated that these buildings were defined early on in the process to provide an anchor for the master plan design. Although the heritage appraisal identified four out of five buildings worthy of retention due to their architectural and social significances, only two are being retained, as a condition assessment stated that the conversion of the buildings and investment required would render the buildings as economically obsolete (DTZ, 2011). For example, although the art deco building (Figure 7) was seen as architecturally significant, there were problems such as spalling concrete, water ingress through the roof and corroding reinforcement bars. Other buildings were identified for demolition because of their lack of architectural interest or lack of adaptation potential based on technical criteria - for example, large open warehouses with very few windows.

\section{Tool analysis}

\subsection{The Transformation Meter}

During stage 1 , the majority of the 'veto criteria' set out by the Transformation Meter were not a concern. However, in a number of buildings which were retained in reality, particularly at Selly Oak Hospital, the floor-to-ceiling height was less than $2.6 \mathrm{~m}$. According to the tool, they should not have been considered for adaptation. This identifies a limitation in using a Dutch tool,

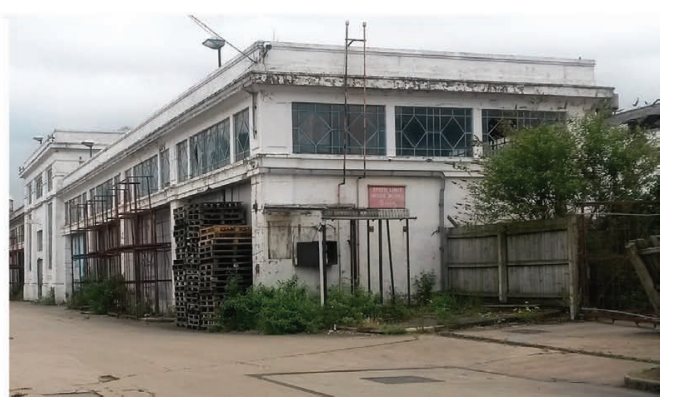

Figure 7. Left: former Stable Block being maintained at Icknield Port Loop site. Right: art deco building being demolished because of poor condition 
where there are different building regulations in the UK; adjustments are required when applying the tool to a different geographical context. Furthermore, the Transformation Meter is designed to assess existing office blocks. Many of the buildings with limited floor-to-ceiling height were already being used for residential purposes, such as the nurses' residences at Selly Oak. These buildings required refurbishment rather than change of use adaptation. The tool could be extended to test alternative adaptation options. For these reasons, the buildings were still tested in stage 2 , despite failing stage 1 .

The results from stage 2 are shown in Figure 8. The majority of criteria were objective and easy to answer as they relate to the technical aspects of the building, such as dimensions. Error bars have been included in this analysis due not only to the availability of data but also to those criteria that are considered subjective, including 'the building is located in a dull environment'.

The tool suggests that Fort Dunlop had the least adaptation potential because of its poor location, surrounding industrial environment, poor condition, lack of natural lighting caused by a deep floor plan $(52 \mathrm{~m})$, high noise levels and the need for remediation on site. This corresponds with the findings from the interviews which suggested that a range of previous architects had difficulties working with the existing structure. The building was converted to offices rather than a residential use, due to the

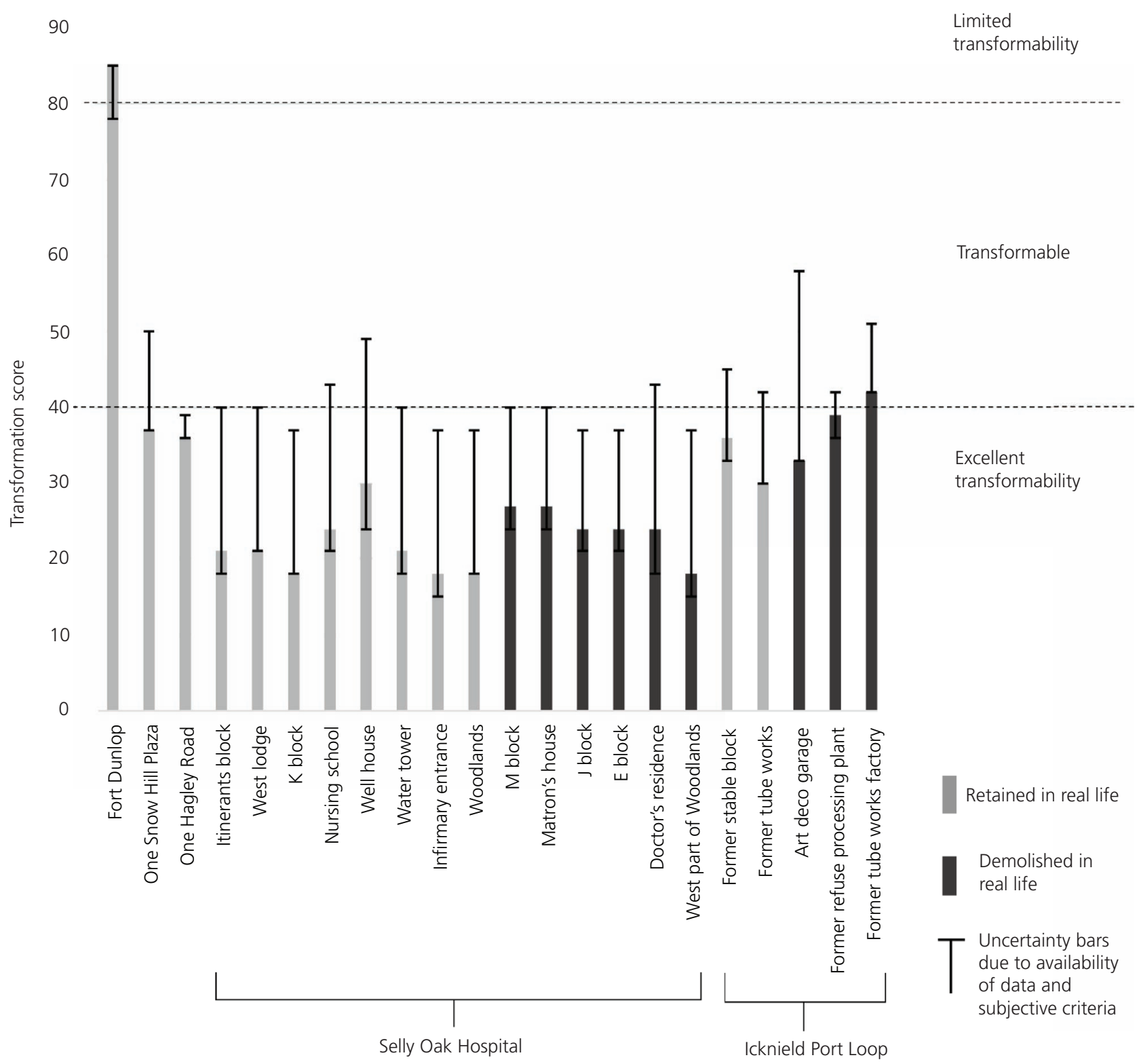

Figure 8. Transformation Meter results for case study investigations 
concerns over noise levels, indicating that the tool could be extended to consider different end uses. However, despite having 'limited transformability', the decision was made to convert rather than demolish the warehouse due to its aesthetic value and importance as a landmark in the surrounding area. These factors were considered to outweigh the technical feasibility and accessibility issues which were the predominant focus of the Transformation Meter.

Hagley Road and Snow Hill Plaza showed good adaptation potential according to the Transformation Meter because of their location to amenities and technical criteria such as the size of the structural grid (e.g. module support structure $<3.60 \mathrm{~m}$ ), floor-toceiling height and ability to increase the number of storeys. In these cases, there was also the added incentive of government initiatives, such as permitted development and the BPRA. If applying the Transformation Meter to asset portfolios in the UK, these should be considered when assessing the financial feasibility of the project (stages 4 and 5).

The results from the tool show that all the buildings on the master plan sites (Selly Oak Hospital and Icknield Port Loop) have good adaptation potential. However, in reality, nine out of the 19 buildings analysed were identified for demolition. Although the tool contains criteria relating to the physical attributes of the building, it does not contain criteria directly related to potential land values and the effect of alterations to the buildings, which were the reasons for demolition. This shows potential for the Transformation Meter to be incorporated into a new tool assessing larger master plan developments, which would include the technical aspects of buildings alongside urban design and land economy variables.

At Icknield Port Loop, despite only two of the five buildings being retained, the tool suggested that they all had adaptability potential. The main reasons for demolition were the poor condition of the buildings and lack of architectural interest. The tool has few criteria relating to the building condition, so this has little effect on the overall score during stage 2. In these cases, the decision is likely to be made in stage 4 , which assesses the financial viability.

Some of the criteria which lessen the adaptation potential of a building according to the decision tool can be overcome by careful design, which is addressed when assessing the risk of the project in stage 5 (T. Van der Voordt, personal communication, 9 January 2017). At Fort Dunlop, the deep plan created difficulties in providing natural lighting; thus, atria were punched through the centre. Although these issues make the adaptation more technically complex and potentially more expensive, the cost here was considered to be outweighed by the intangible values associated with the building, such as its heritage value. Developers and asset owners should not, therefore, be discouraged by the tool if these problems can be overcome through innovative design. Overall, the tool is useful for its intended purpose of rapidly assessing a portfolio of assets, but should not be relied on in its entirety, as other factors need to be considered in these complex decisions. This is recognised by the tool's creator, who states that 'the transformation potential score just gives an indication but will not define the final decision. That is up to the decision-makers' (T. Van der Voordt, personal communication, 9 January 2017).

\subsection{IconCUR}

Figure 9 displays the results of the IconCUR analysis ( $x$ and $y$ axes only). Fort Dunlop produced low scores for both the condition and utilisation (trending decision towards demolition) because the building had problems with spalling concrete and meeting current regulations (in particular, fire), and it had been vacant for over 20 years. This highlights the importance of considering the $z$ axis, reward, as this is where the impact of the decision is evaluated, including the conservation of heritage.

Hagley Road and Snow Hill Plaza both received scores suggesting that they should be refreshed or reused/adapted, in agreement with the real-life decisions. For the Selly Oak buildings, similar to the results from the Transformation Meter, the IconCUR framework indicates that all the buildings are reusable or could be adapted. The difference between individual building scores for utilisation is caused by the former use. For

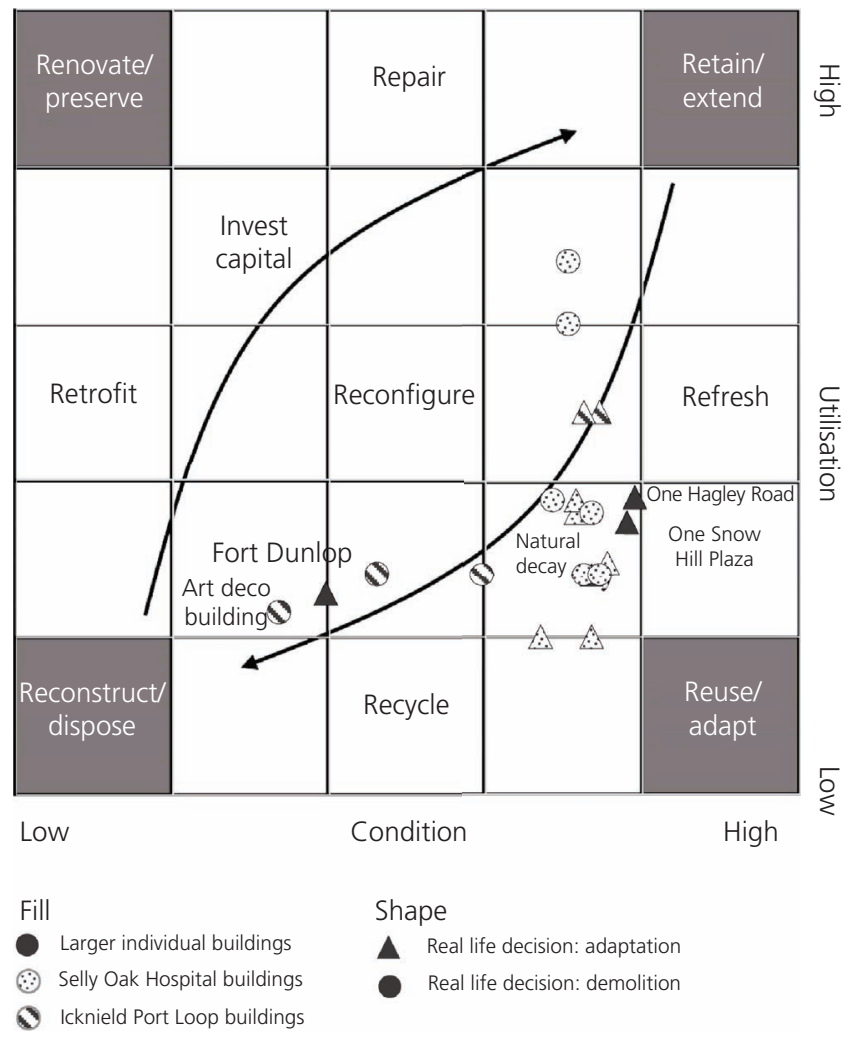

Figure 9. IconCur results ( $x$ and $y$ axes only). Background image reproduced from Wilkinson et al. (2014: pp. 230-249) 
example, some of the buildings on the hospital site were used for residential purposes, so they scored higher than the former hospital wards in terms of fitness for purpose. As discussed previously, the overriding decision for demolition on Selly Oak Hospital was the compromised architectural quality, which is not explicitly referred to in the $x$ or $y$ axis, and the maximisation of land, an urban design issue. For the buildings at Icknield Port Loop, the results show a clear distinction between the buildings in good and poor conditions as this is a fundamental criterion in the analysis. This corresponds with the real-life decisions which saw the buildings in poor condition demolished because the option of adaptation was uneconomic.

The $z$ axis in the IconCUR tool considers the stakeholder interest and collective utility, if the buildings were adapted rather than demolished. This includes the profile of the project and the opportunity to add value. The score looks at the building in its current state and a further analysis uses the same scoring system to indicate the reward after intervention. Fort Dunlop had the biggest impact (Figure 10) due to factors associated with high economic returns and conservation of heritage which, in turn, raised stakeholder interests. One of the buildings at Icknield Port Loop scored the lowest because of lower environmental values, alongside a lack of heritage/cultural characteristics, resulting in less of a positive impact to the community and other stakeholders. It is vital that this $z$ axis is considered when using the tool as it begins to explore the impact and value of the decisions being made.

As the criteria are assigned a number from 1 to 5 , there is a degree of uncertainty. It would also be beneficial to have more people assign marks for the buildings and take average values to reduce bias/error.

\subsection{Discussion}

The analysis of the Transformation Meter and IconCUR compared with real-life decisions shows that both tools are useful in giving an indication of whether a building should be adapted or demolished, within their intended purpose of assessing a portfolio of building assets. However, potential improvements could be made by integrating other factors. One of these is to give a stronger weighting to intangible values, such as heritage, to reflect reality better, at least within the UK context. For example, for Fort Dunlop, although the adaptation was a technically complex project, the decision-makers saved the building because of its importance to the community. The case study showed that innovative design approaches can help overcome technical issues and that the possibility of adaptation should not be dismissed based on either tool's results. Alongside this, the Transformation Meter could be extended to assess different uses and degrees of adaptation.

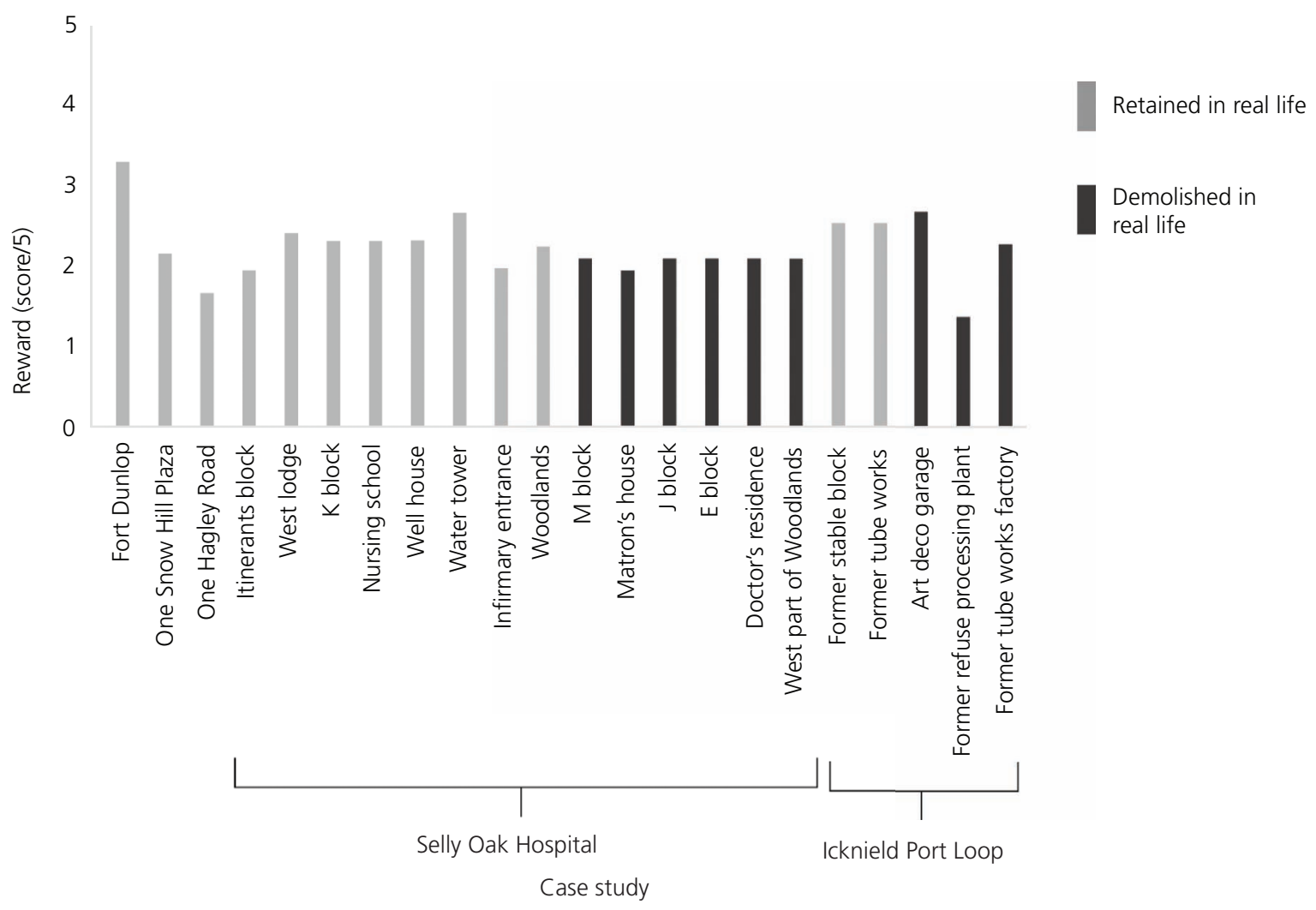

Figure 10. IconCUR - reward scores ( $z$ axis) post-intervention - assuming all buildings are adapted ( 5 = highest reward) 
The decision-making tools were not designed in the UK. Adjustments are required for using the tool in a different geographical context to that for which it was created, as building regulations, planning conditions, cultural contexts and government incentives differ. This needs to be recognised if practitioners and researchers choose to work with the tools in different countries, as government incentives were a key driver for adaptation in two of the case studies investigated.

Most importantly, from the analysis of the two case studies of multiple buildings across large sites, these tools are not yet appropriate to analyse developments at a master plan level as other factors need to be considered, such as land efficiency and values. For Selly Oak Hospital, despite the Transformation Meter showing that all the locally listed buildings had good adaptation potential, in reality, it was not seen as economically viable to keep them all, and compromises had to be made by keeping some while demolishing others.

\section{Conclusions and future work}

This paper provides a comparative assessment of case study investigations involving the decision to demolish or adapt existing buildings and uses the findings to evaluate theoretical design tools. Both the Transformation Meter (Geraedts and Van der Voordt, 2007) and IconCUR (Langston and Smith, 2012) were designed to assess rapidly buildings within a portfolio of assets to decide what the most appropriate form of intervention should be. According to the case studies, reasons for retention included conserving heritage, the importance of buildings to the community, government incentives such as permitted development - and architectural quality; while reasons for demolition were compromised architectural significance, the land could be used more effectively and poor building condition, causing the schemes to be uneconomically viable.

The evaluation of design tools showed that they were suitable for their intended purpose but that there are potential improvements. For example, intangible values such as heritage need to be viewed on an equal footing with the technical characteristics, and it should not be forgotten that the tools are only a guide and that innovative design solutions can help overcome technical difficulties. Additionally, the tools could be extended to assess different end uses and forms of adaptation.

Adjustments are required when using the decision tools on larger sites with multiple buildings. Currently, compromises that may be needed when more than one building is being assessed for adaptation within the same area and issues such as land value and urban design variables are not integrated. This provides an opportunity for further work assessing the decision to demolish or adapt at a master plan level, which can incorporate and build on these existing decision-making tools.

Alongside this, the impact of the decision should be evaluated, as the decisions currently made may not necessarily be the most appropriate ones in terms of sustainability. Langston and Smith
(2012) have begun to incorporate this through the $z$ axis (reward) in IconCUR, and Langston has created an additional sustainability framework which evaluates adaptation projects (Wilkinson et al., 2014). Future work could evaluate this framework alongside others for their applicability in sustainable decision-making.

\section{Acknowledgements}

The authors gratefully acknowledge the Engineering and Physical Sciences Research Council (EPSRC) for funding this research through the EPSRC Centre for Doctoral Training in Future Infrastructure and Built Environment (EPSRC grant reference number EP/L016095/1) and would like to thank all those that agreed to be interviewed and contributed to this project.

\section{REFERENCES}

Advantage West Midlands (2012) Advantage West Midlands - Making a Difference - 1999. Advantage West Midlands, Birmingham, UK.

Ahlfeldt GM, Holman N and Wendland N (2012) An Assessment of the Effects of Conservation Areas on Value. Historic England, London, UK. See http://www.english-heritage.org.uk/ (accessed 01/05/2016). Anon (2008) First phase of No 1 Snow Hill development is set to take shape. Birmingham Post, 4 December. See https://www.thefreelibrary. $\mathrm{com} /$ First + phase + of $+\mathrm{No}+1+$ Snow + Hill + development + is + set + to + take +shape.-a0190027095 (accessed 28/11/2016).

Associated Architects (2012) No. 1 Hagley Road: Birmingham Planning, Design, Access and Heritage Statement. Henserson Global Investors, London, UK.

Ball RM (2002) Re-use potential and vacant industrial premises: revisiting the regeneration issue in Stoke-on-Trent. Journal of Property Research 19(2): 93-110, http://dx.doi.org/10.1080/ 09599910210125223.

Been V, Ellen IG, Gedal M, Glaeser E and McCabe BJ (2016) Preserving history or restricting development? the heterogeneous effects of historic districts on local housing markets in New York City. Journal of Urban Economics 92: 19-30, http://dx.doi.org/10.1016/ j.jue.2015.12.002.

Birmingham City Council (2011) Details Page for Planning Application 2011/07399/PA. Birmingham City Council, Birmingham, UK. See https://eplanning.birmingham.gov.uk/Northgate/PlanningExplorer/ Generic/StdDetails.aspx?PT=Planning\%20Applications\%20OnLine \&TYPE $=$ PL/PlanningPK.xml\&PARAM0 $=554563 \& X S L T=/$ Northgate/PlanningExplorer/SiteFiles/Skins/Birmingham/xslt/PL/ PLDetails.xslt\&FT=Planning\%20Application\%20Details\&PUBLIC $=$ Y\&XMLSIDE=/Northgate/PlanningExplorer/SiteFiles/Skins/ BirminghamNew/Menus/PL.xml\&DAURI=PLANNING (accessed 24/02/2017).

Birmingham City Council (2015) Big City Plan - City Centre Masterplan. Birmingham City Council, Birmingham, UK.

Brown G (2014) One Hagley Road apartments sold out within five months of launch. Birmingham Post, 2 October. See http://www. birminghampost.co.uk/business/business-news/one-hagley-roadapartments-sold-7867350 (accessed 21/11/2016).

Building Design Group Ltd (2014) Design \& Access Statement for $12 \mathrm{New}$ Residential Apartments at One Hagley Road, Birmingham. Birmingham City Council, Birmingham, UK.

Bullen PA and Love PED (2010) The rhetoric of adaptive reuse or reality of demolition: views from the field. Cities 27(4): 215-224, http://dx.doi.org/10.1016/j.cities.2009.12.005.

Bullen PA and Love PED (2011) A new future for the past: a model for adaptive reuse decision-making. Built Environment Project and Asset Management 1(1): 32-44, http://dx.doi.org/10.1108/ 20441241111143768. 
Clegg P (2012) A practitioner's view of the 'Regenerative Paradigm'. Building Research \& Information 40(3): 365-368, http://dx.doi.org/10. 1080/09613218.2012.663557.

Conejos S, Langston C and Smith J (2011) Improving the implementation of adaptive reuse strategies for historic buildings. Proceedings of Le Vie dei Mercanti S.A.V.E. Heritage: Safeguard of Architectural, Visual, Environmental Heritage, Naples, Italy.

Daly S, McGowan A and Papalambros P (2013) Using qualitative research methods in engineering design research. Proceedings of the 19th International Conference on Engineering Design (ICED13), Design for Harmonies, vol. 2: Design Theory and Research Methodology, Seoul, Korea, pp. 203-212, DS 75-2.

Davis Langdon (2008) Opportunities for Existing Buildings - Deep Emission Cuts. Davis Langdon, Sydney, Australia.

DCLG (Department for Communities and Local Government) (2012) National Planning Policy Framework. Her Majesty's Stationary Office, London, UK. See https://www.gov.uk/government/uploads/ system/uploads/attachment_data/file/6077/2116950.pdf (accessed 09/02/2017).

DCLG (Department for Communities and Local Government) and Lewis B (2016) Landmark Housing and Planning Bill Receives Royal Assent. Department for Communities and Local Government, London, UK. See https://www.gov.uk/government/news/landmark-housing-andplanning-bill-receives-royal-assent (accessed 31/07/2016).

Dixon T, Raco M, Catney P and Lerner DN (2008) Sustainable Brownfield Regeneration: Liveable Places from Problem Spaces. Wiley, Hoboken, NJ, USA.

Douglas J (2006) Building Adaptation, 2nd edn. Routledge, London, UK. DTZ (Debenham Thouard Zadelhoff) (2011) Overview Condition Report: Relating to: Unit H Factory and Art Deco Garage Rotton Park Street, Icknield Port Loop Birmingham. Birmingham City Council, Birmingham, UK.

Dutta M and Husain Z (2009) An application of multicriteria decision making to built heritage: the case of Calcutta. Journal of Cultural Heritage 10(2): 237-243, http://dx.doi.org/10.1016/j.culher.2008.09.007.

EGi (2015) Building Report: Prologis Park - Fort Dunlop, Fort Parkway, Birmingham. Estates Gazette, London, UK.

Falconer Chester Hall (2010) Change of Use Application to Create a Hotel \& Conferencing Facilities - Design \& Access Statement. Birmingham City Council, Birmingham, UK.

Gaspar PL and Santos AL (2015) Embodied energy on refurbishment vs demolition: a southern Europe case study. Energy and Buildings 87: 386-394, http://dx.doi.org/10.1016/j.enbuild.2014.11.040.

Geraedts R and Van der Voordt T (2007) A tool to measure opportunities and risks of converting empty offices into dwellings. European Network for Housing Research (ENHR) International Conference, Sustainable Urban Areas, Rotterdam, the Netherlands.

Historic England (2016) Building Regulations Compliance: Listed Buildings and Other Heritage Assets. Historic England, London, UK. See https://historicengland.org.uk/advice/hpg/compliantworks/ buildingregs/ (accessed 01/05/2016).

HMG (Her Majesty's Government) (2010) The Building Regulations 2010. The Stationery Office, London, UK. Statutory Instrument 2010 No. 2214. See http://www.legislation.gov.uk/uksi/2010/2214/regulation/3/ made (accessed 01/05/2016).

HMG (2013) The Town and County Planning (General Permitted Development) (Amendment) (England) Order 2013. The Stationery Office, London, UK, Statutory Instrument 2013 No. 1101.

HMRC (Her Majesty's Revenue \& Customs) (2014) CA45100: Business Premises Renovation Allowance (BPRA): Background and Outline HM Revenue \& Customs, London, UK. See https://www.gov.uk/ hmrc-internal-manuals/capital-allowances-manual/ca45100 (accessed 20/07/2016).

Housing and Planning Act 2016. Chapter 22. Her Majesty's Stationery Office, London, UK.
IStructE (Institution of Structural Engineers) (2008) Guide to Surveys and Inspections of Buildings and Associated Structures. IStructE, London, UK

Itard L and Klunder G (2007) Comparing environmental impacts of renovated housing stock with new construction. Building Research \& Information 35(3): 252-267, http://dx.doi.org/10.1080/ 09613210601068161

Kutut V, Zavadskas EK and Lazauskas M (2014) Assessment of priority alternatives for preservation of historic buildings using model based on ARAS and AHP methods. Archives of Civil and Mechanical Engineering 14(2): 287-294, http://dx.doi.org/10.1016/j.acme.2013.10. 007.

Langston C and Smith J (2012) Modelling property management decisions using 'iconCUR'. Automation in Construction 22: 406-413, http://dx.doi.org/10.1016/j.autcon.2011.10.001.

Lazrak F, Nijkamp P, Rietveld P and Rouwendal J (2013) The market value of cultural heritage in urban areas: an application of spatial hedonic pricing. Journal of Geographical Systems 16(1): 89-114, http://dx.doi.org/10.1007/s10109-013-0188-1.

Lin G and Low S (2012) Influential criteria for building adaptation potential from the perspective of decision makers. Proceedings of the 48th ASC Annual International Conference, Birmingham, $U K$.

Love P and Bullen P (2009) Toward the sustainable adaptation of existing facilities. Facilities 27(9/10): 357-367, http://dx.doi.org/10.1108/ 02632770910969603.

May T (2003) Social Research: Issues, Methods and Process, 3rd edn. Open University Press, Buckingham, UK.

McAllister S (2006) Hard Fort Battle. Property Week, London, UK. See http://m.propertyweek.com/news/hard-fort-battle/3061657.article (accessed 21/11/2016).

Noonan DS and Krupka DJ (2011) Making - or picking - winners: evidence of internal and external price effects in historic preservation policies. Real Estate Economics 39(2): 379-407, http://dx.doi.org/ 10.1111/j.1540-6229.2010.00293.x.

Oxford Dictionaries (2016) Heritage. In Oxford Dictionary. Oxford University Press, Oxford, UK. See http://www.oxforddictionaries.com/ definition/english/heritage (accessed 01/05/2016).

Palmer J, Platt S, Fawcett W et al. (2003) Report to the Energy Savings Trust. Refurbish or Replace? Context Report. Cambridge Architectural Research Ltd, Cambridge, UK.

Picco M, Dyck A and Botelho R (2012) Structural Condition Assessment. Picco Engineering Ltd, Brantford, ON, Canada.

Pinder J, Schmidt R III and Saker J (2013) Stakeholder perspectives on developing more adaptable buildings. Construction Management and Economics 31(5): 440-459, http://dx.doi.org/10.1080/01446193.2013. 798007.

Pinsent Masons (2015) Pinsent Masons Advises Developer on $£ 100$ Million Investment for Selly Oak. Pinsent Masons, London, UK. See http://www.pinsentmasons.com/en/media/press-releases/2015/ pinsent-masons-advises-developers-100-million-investment-for-sellyoak-/ (accessed 02/05/2016).

Plevoets B and Van Cleempoel K (2011) Adaptive reuse as a strategy towards conservation of cultural heritage: a literature review. In Structural Studies, Repairs and Maintenance of Heritage Architecture XII (Brebbia C and Binda L (eds)). WIT Press, Chianciano Terme, Italy, pp. 155-164.

Plimmer F, Pottinger G, Harris S, Waters M and Pocock Y (2008) Knock It Down or Do It Up? Sustainable Housebuilding: New Build and Refurbishment in the Sustainable Communities Plan. IHR BRE Press, Oldbury, UK

Power A (2008) Does demolition or refurbishment of old and inefficient homes help to increase our environmental, social and economic viability? Energy Policy 36(12): 4487-4501, http://dx.doi.org/10.1016/ j.enpol.2008.09.022. 
Remøy $\mathrm{H}$ and Van der Voordt T (2006) A new life: transformation of vacant office buildings into housing. Proceedings of the CIB W70 Trondheim International Symposium Changing User Demands on Buildings, Trondheim, Norway.

Ruijgrok ECM (2006) The three economic values of cultural heritage: a case study in the Netherlands. Journal of Cultural Heritage 7(3): 206-213, http://dx.doi.org/10.1016/j.culher.2006.07.002.

ShedKM (2008) ShedKM Red Book. ShedKM Ltd, Liverpool, UK. See http://www.shedkm.co.uk/pdf/shedkm\%20red\%20book.pdf (accessed 09/02/2017).

Smith L (2016) Planning Reform Proposals. House of Commons Library, London, UK, Briefing Paper No. 06418.

Thomsen A and van der Flier K (2009) Replacement or renovation of dwellings: the relevance of a more sustainable approach. Building Research \& Information 37(5-6): 649-659, http://dx.doi.org/10.1080/ 09613210903189335.

UHB (University Hospitals Birmingham National Health Service Foundation Trust) and GVA Grimley Ltd. (2012) Locally Listed Building Retention/Conversion Assessment - Selly Oak Hospital. Birmingham City Council, Birmingham, UK.

Urban Splash (2007) Tea and Tyres at Fort Dunlop. Urban Splash, Manchester, UK. See http://www.urbansplash.co.uk/news/pressreleases/tea-and-tyres-at-fort-dunlop (accessed 18/07/2016).
Van der Flier K and Thomsen A (2006) Life cycle of dwellings: analysis and assessment of demolition by Dutch Housing Associations. Proceedings of the ENHR Conference 'Housing in an Expanding Europe: Theory, Policy, Participation and Implementation', Ljubljana, Slovenia.

Wang HJ and Zeng ZT (2010) A multi-objective decision-making process for reuse selection of historic buildings. Expert Systems with Applications 37(2): 1241-1249, http://dx.doi.org/10.1016/j.eswa.2009. 06.034 .

Watson P (2009) The key issues when choosing adaptation of an existing building over new build. Journal of Building Appraisal Impact \& Description 4(3): 215-223, http://dx.doi.org/10.1057/jba. 2008.39 .

Wilkinson S (2011) The Relationship between Building Adaptation and Property Attributes. PhD thesis, Deakin University, Melbourne, Australia.

Wilkinson SJ, Remøy H and Langston C (2014) Sustainable Building Adaptation: Innovations in Decision-Making, 1st edn. Wiley-Blackwell, Chichester, UK.

Yung EHK and Chan EHW (2012) Implementation challenges to the adaptive reuse of heritage buildings: towards the goals of sustainable, low carbon cities. Habitat International 36(3): 352-361, http://dx.doi. org/10.1016/j.habitatint.2011.11.001.

\section{How can you contribute?}

To discuss this paper, please email up to 500 words to the editor at journals@ice.org.uk. Your contribution will be forwarded to the author(s) for a reply and, if considered appropriate by the editorial board, it will be published as discussion in a future issue of the journal.

Proceedings journals rely entirely on contributions from the civil engineering profession (and allied disciplines). Information about how to submit your paper online is available at www.icevirtuallibrary.com/page/authors, where you will also find detailed author guidelines. 